\title{
Comparison of Mild Cognitive Impairment Between the Older People with Diabetes Mellitus and without Diabetes Melitus
}

\author{
Wijaya Taufik Tiji* Mustafa M Amin Elmeida Effendy Dharma Lindarto \\ Faculty of Medicine, University of Sumatera Utara, Jalan dr. Mansur No 5 Medan 20155, Sumatera \\ Utara \\ * E-mail of the corresponding author: dr.taufik@yahoo.com
}

\begin{abstract}
Dementia is a disease that is most common and most damaging in the elderly. Nearly 4.6 million new cases are found each year and is found in the number doubled every 20 year and it is estimated there are 81.1 million people in the year 2040. (Velayudhan L, Poope M, Archer N, Proitsi G, Brown R, lovestone S.(2010)). Luchsinger and colleagues found that diabetes mellitus have an increased risk propensity on samples were nonamnestic mild cognitive impairment. The risk of mild cognitive impairment caused by diabetes mellitus was $8.8 \%$ for the entire sample and is higher in African-American population of $8.4 \%$ and a population Hispanik11,0\% compared with the Non-Hispanic whites were $4.6 \%$ reflecting prevalence of diabetes mellitus in minority populations in the United States. (Luchsinger JA, Reitz C, patel B, Tang MX, Manly JJ, Mayeux R.(2007)).This study was a cross sectional study. Place of research: Geriatric Clinic, Clinic of Internal Medicine Endocrine SMF RSUP.H.Adam Malik and Lions Club of Medan City Polyclinic jl. Anggrung no.5. Periode 10 February 2011 until May 2011. Any patients who met the inclusion and exclusion criteria were included in the study will be done when blood sugar levels which will then be followed by a fasting blood sugar levels in the next day and on the same day the patient will psychiatric interview examination. All data collected will be analyzed further. Results from this study, of the 124 samples obtained, there were 38 samples (30.6\%) with a normal MMSE interpretation, 24 samples (19.4\%) with interpretation of probable cognitive impairment and 62 samples (50\%) who had a definite interpretation of cognitive impairment. By chi square analysis found as many as 38 people who had a normal MMSE score interpretation consisted of $73.7 \%$ men and $26.3 \%$ women. of 24 samples of group interpretation MMSE score, probable cognitive impairment found $41.7 \%$ of men and $52.3 \%$ women and 62 samples of definite cognitive impairment found $38.7 \%$ of men and $61.3 \%$ of women with a figure of significance $0.002(\mathrm{p}<0.05)$. With Kolmogorov- Smirnov analysis can be seen that there are 30 samples or $24.19 \%$ of the sample who did not have diabetes mellitus who had a probable interpretation of MMSE cognitive impairment and 27 samples or $21.77 \%$ of the sample who had diabetes mellitus who also had MMSE interpretation, probable disturbance cognitive significance with the number $0.269(p>0.05)$. In the study showed that the elderly can experience mild cognitive impairment and diabetes mellitus have a role in the incidence of mild cognitive impairment in the elderly.
\end{abstract}

Keywords: cognitive impairment, diabetes mellitus

\section{Introduction}

Dementia is a disease that is most common and most damaging in the elderly. Nearly 4.6 million new cases are found each year and is found in the number doubled every 20 year and it is estimated there are 81.1 million people in 2040.(Velayudhan L, Poope M, Archer N, Proitsi G, Brown R, lovestone S.(2010)). Patients with mild cognitive impairment (mild cognitive impairment / MCI) has increased to dementia risk, although the conversion rate is reported to range between $1-25 \%$ or more annually. Prediction of progression of dementia conversion is an important clinical consideration. Diabetes mellitus is always associated with the incidence of cognitive dysfunction. Diabetes mellitus type 2 has no effect in accelerating cognitive decline in the elderly, which will develop into mild cognitive impairment and who would later develop into dementia, vascular dementia including Alzheimer's and diseases. There is strong evidence that diabetes mellitus is a risk factor for dementia. (Velayudhan L, Poope M, Archer N, Proitsi G, Brown R, lovestone S.(2010)).

In Luchsinger and colleagues research, of the 334 subjects who suffered from mild cognitive impairment there were 160 who had amnestic mild cognitive impairment and 174 who had non-amnestic mild cognitive impairment. Based on the research results also showed that diabetes mellitus have an increased risk propensity on the subject of non-amnestic mild cognitive impairment. The risk of mild cognitive impairment caused by diabetes mellitus was $8.8 \%$ for the whole subject, and was higher in African-American population of $8.4 \%$ and a population Hispanik11,0\% compared with the Non-Hispanic whites were $4.6 \%$ reflecting prevalence of diabetes mellitus in minority populations in the United States. (Luchsinger JA, Reitz C, patel B, Tang MX, Manly JJ, Mayeux R.(2007)). 
According Velayudhan et al, diabetes mellitus not only increases the risk of incident dementia and mild cognitive impairment but also increases the risk of progression of mild cognitive impairment into demensia.1 This is evident in the results of his research, which among 165 participants who suffered from mild cognitive impairment, 103 people meet the criteria Peterson. The mean age of the study cohort at baseline was 79.4 years and 66 years in women. In their study, of the 103 participants, 16\% died, $6 \%$ failed to follow-up, 3\% moved, 16\% refused to participate in the study. Total of 61 participants were successfully followed up for four years. The participants were compared according to socio-demographic profile, risk factors, and clinical parameters of the incomplete follow-up. $16 \%$ of patients diagnosed with diabetes with a mean duration of diabetes of 9.3 years. Among the 61 participants who successfully completed their follow-up, 31\% suffered from dementia, 3\% can improve cognitive towards normal cognitive level, 59\% remained the same as originally. (Velayudhan L, Poope M, Archer N, Proitsi G, Brown R, lovestone S.(2010)). By looking at the above results the researchers were interested to know whether it also occurs in Indonesia.

\section{Subject and Methods}

This study was approved by the Research Ethics Committee of Medical Faculty University of Sumatera Utara. This study was a cross sectional study in which all older people who come will be examined their MMSE score and then will be compared among the elderly who suffer with diabetes mellitus who do not have diabetes mellitus at the time of observation. This study will be done at Geriatric Clinic, Clinic of Internal Medicine Endocrine SMF RSUP.H.Adam Malik and Lions Club of Medan City Polyclinic from February 2011 until May 2011.

Subjects were patients aged greater than or equal to 65 years who came for treatment to the Clinic of Endocrinology and Geriatrics Clinic RSUP.H.Adam malik. Selection of subjects by non-probability sampling types consecutive sampling. Inclusion criteria were: Men and women who aged $\geq 65$ years can speak Indonesian and want to participate in this study. The exclusion criteria are: Have a history of stroke , schizophrenia and other psychotic disorders. Have a history of substance abuse and have a history suffering from depression

\subsection{Assessment and Rating}

Each patient enrolled in the study will be conducted during the examination of blood sugar levels which will then be followed by a fasting blood sugar levels in the next day and on the same day the patient will be examined psychiatric interview. All data collected will be analyzed further.

\subsection{Statistical Analysis}

Primary data is data obtained from direct examination on the subject of the study after signing an affidavit willing to participate in research. Data obtained from research subjects are recorded and put into groups according to their kinds. The data have been obtained, collected, processed and analyzed with the chi-square test with the software Statistical Package For Social Science (SPSS) version 15.0.

\section{Result}

A total of 62 patients who came to the clinic for treatment of geriatrics and endocrinology clinic RSUP.H.Adam Malik and social Polyclinic Lions Club of Medan City, participated in the study. From February 1, 2011 until May 31, 2011.

Table 1. Frequency of Samples Based on MMSE scores

\begin{tabular}{ccc}
\hline MMSE & Frequence & Percentage \\
Normal & 19 & $\mathbf{3 0 , 6}$ \\
Borderline & 12 & 19,4 \\
Probable & 31 & 50 \\
\hline Total & 62 & 100 \\
\hline
\end{tabular}


From table 1 above it can be seen that of the 62 subjects were obtained, there were 19 subjects (30.6\%) with a normal MMSE interpretation, 12 subjects (19.4\%) with threshold interpretation and 31 subjects (50\%) who have interpretation who may haventia.

Table 2 Interpretation of MMSE scores by gender

\begin{tabular}{|c|c|c|c|c|c|}
\hline & & \multicolumn{3}{|c|}{ MMSE } & \multirow[b]{2}{*}{$\mathbf{P}$} \\
\hline & & NORMAL & BORDERLINE & PROBABLE & \\
\hline \multirow{5}{*}{ Gender } & MALE & 14 & 5 & 12 & \\
\hline & & $(73,7 \%)$ & $(41,7 \%)$ & $(38,7 \%)$ & \\
\hline & FEMALE & 5 & 7 & 19 & \\
\hline & & $(26,3 \%)$ & $(\mathbf{5 8 , 3 \%})$ & $(61,3 \%)$ & 0,046 \\
\hline & TOTAL & $\begin{array}{l}19 \\
(100 \%)\end{array}$ & $\begin{array}{l}12 \\
(100 \%)\end{array}$ & $\begin{array}{l}31 \\
(100 \%)\end{array}$ & \\
\hline
\end{tabular}

From Table 2 above were analyzed by chi square analysis found as many as 19 people who had a normal MMSE score interpretation consisted of $73.7 \%$ men and $26.3 \%$ women. group of 12 subjects MMSE score interpretation, the threshold found $41.7 \%$ of men and $52.3 \%$ women and the possibility of 31 subjects with dementia found $38.7 \%$ of men and $61.3 \%$ of women with a figure of significance $0.046(\mathrm{p}<0.05)$ indicating that there are significant differences between men and women who have a normal MMSE interpretation, threshold or the possibility of suffering from dementia.

Table 3 Table Interpretation Blood Sugar Level by gender

\begin{tabular}{lllll} 
& & \multicolumn{3}{c}{ BLOOD SUGAR LEVEL } \\
& & DIABETES MELITUS & NORMAL & P \\
\hline Gender & Male & 18 & 13 & \\
& & $(58,1 \%)$ & $(41,9 \%)$ & 0,204 \\
& Female & 13 & 18 & \\
& & $(41,9 \%)$ & $(58,1 \%)$ & \\
& Total & 31 & 31 \\
& $(100 \%)$ & $(! 00 \%)$
\end{tabular}

From Table 3 above it can be seen that $50 \%$ or as many as 31 subjects who suffered diabetes mellitus, and $50 \%$ of the subjects contained $58.1 \%$ of male subjects with diabetes mellitus and $41.9 \%$ of subjects were women with significant numbers 0.204 ( $\mathrm{p}>0.05$ ) indicating that there is no significant difference between men who suffer with diabetes mellitus who do not have diabetes mellitus.

Table 4 Relationship Between MMSE and Interpretation Interpretation Blood Sugar Level

\section{Blood sugar level}

\begin{tabular}{llllll} 
& & Diabetes Melitus & Normal & Total & P \\
\hline MMSE & Normal & $\mathbf{1 2}$ & $\mathbf{7}$ & $\mathbf{1 9}$ \\
& & $(\mathbf{3 8 , 7} \%)$ & $(\mathbf{2 2 , 6} \%)$ & $(\mathbf{3 0 , 6 \% )}$ & $\mathbf{0 , 2 6 2}$ \\
& Borderline & $\mathbf{4}$ & $\mathbf{8}$ & $\mathbf{1 2}$ & $(\mathbf{1 9 , 4 \% )}$ \\
& $(\mathbf{1 2 , 9} \%)$ & $(\mathbf{2 5 , 8} \%)$ & $\mathbf{1 6}$ & $\mathbf{3 1}$ \\
& Probable & $\mathbf{1 5}$ & $(\mathbf{5 1 , 6} \%)$ & $(\mathbf{5 0 \% )}$ \\
\hline & $(\mathbf{4 8 , 4 \% )}$ & $\mathbf{3 1}$ & $\mathbf{6 2}$ \\
& & $\mathbf{3 1}$ & $(\mathbf{1 0 0} \%)$ & $(\mathbf{1 0 0 \% )}$ \\
\hline
\end{tabular}

From the table above it can be seen that there are 8 subjects or $25.8 \%$ of subjects without diabetes mellitus who have MMSE interpretation threshold and 4 subjects, or $12.9 \%$ of the subjects with diabetes mellitus 
who also have the interpretation of the MMSE, 0.262 significance threshold with numbers ( $\mathrm{p}>0.05$ ). This means there is no significant difference on mild cognitive impairment among elderly people who suffer from diabetes mellitus with without diabetes mellitus.

\section{Discussion}

Comparative study of mild cognitive impairment in elderly people who suffer from diabetes mellitus and without diabetes mellitus is a cross sectional study with one time observation. This study chose a group of patients with diabetes mellitus and normal group of patients over the age of 60 years and the functions of daily life are still intact / intact as a subject.

From table 1 above it can be seen that of the 62 subjects were obtained, there were 19 subjects $(30.6 \%)$ with a normal MMSE interpretation, 12 subjects (19.4\%) with threshold interpretation and 31 subjects $(50 \%)$ who have interpretation who may have dementia. In patients who experienced a decline in MMSE scores that are on the brink of a group can be interpreted to experience mild cognitive impairment according to the diagnostic criteria made by the Mayo Clinic Alzheimer's Disease Research Center (MCDRC). (Petersen RC, Smith GE, Waring SC, Ivnik RJ, Tangalos EG, kokmen E. (1999))

From table 4 above it can be seen that there are 8 subjects or $25.8 \%$ of subjects without diabetes mellitus who have mild cognitive impairment and 4 subjects, or $12.9 \%$ of the subjects with diabetes mellitus were also mild cognitive impairment. The results showed that in elderly people with mild cognitive impairment can occur or the possibility of dementia, according to Luchsinger et al study. From Table 4 also can be seen that both in patients with diabetes mellitus or who do not have diabetes mellitus may experience mild cognitive impairment, as much as $12.9 \%$, but the results of this study differ from the study Luchsinger and colleagues who have mild cognitive impairment risk caused by diabetes mellitus was $8.8 \%$ for the whole subject.( Luchsinger JA, Reitz C, patel B, Tang MX, Manly JJ, Mayeux R.(2007)).

This study has several limitation, first, this study was a cross sectional study with a single observation, so that the data is the data that is collected while. And second, subjects with diabetes mellitus, have the possibility of confounding factors such as patients suffering from hypertension or other cardiovascular disease.

\section{Conclusion}

Mild cognitive impairment is defined as a syndrome usually found in the elderly, which is characterized by the impairment of cognitive ability, although clearly represented on the basis of the patient's premorbid weight is not enough to produce a significant impairment of day-to-day. Diabetes mellitus is also berhubungkan with impairment of cognitive function and increased risk for dementia, including Alzheimer's disease. In the study showed that the elderly parent can experience mild cognitive impairment and diabetes mellitus have a role in the incidence of mild cognitive impairment in the elderly.

\section{References}

Velayudhan L, Poope M, Archer N, Proitsi G, Brown R, lovestone S.(2010),” Risk Of Developing Dementia In People With Diabetes And Mild Cognitive impairment". British Journal of psychiatry 196;36-40

Sjahrir H, Ritarwan K, Tarigan S,Rambe A, Lubis I,Bhakti I.(2001)," The Mini mental state examination in healthy individuals in medan, indonesia by age and education level". Neurol j southeast asia ; 6; 19-22

Nasrun MW. (2010), "Demensia”. In Buku ajar psikiatri. Badan penerbit Fakultas Kedokteran Universitas Indonesia. Jakarta : p. $494-504$.

Damping C. (2010), "Psikiatri geriatrik". In buku ajar psikiatri. Badan penerbit Fakultas Kedokteran Universitas Indonesia. Jakarta. p.455 - 66

Moore D. (2008). "Syndromes Of Cognitive Impairment". In textbook of clinical neuropsychiatry. Second edition. Hodder Arnold. London ; P 173 - 74.

Tasman A, Kay J, Lieberman J, First M, Maj M.(2008). "Dementia”. In psychiatry third edition. WileyBlackwell. England. P.898 - 902.

Marder E, Carew T, Essen D. "Diabetes, the brain and cognition", In Brain briefing

Petersen RC, Smith GE, Waring SC, Ivnik RJ, Tangalos EG, kokmen E. (1999). "Mild cognitive impairment clinical characterization and outcome". Arch neurol ; 56 ; 303-308.

Luchsinger JA, Reitz C, patel B, Tang MX, Manly JJ, Mayeux R.(2007). "Relation of diabetes to mild cognitive impairment". Arch Neuro; 64; 570-575

American Psychiatric Association. "Dementia". In Diagnostic And Statistical Manual of Mental Disorders Fourth Edition Text Revision ; P 147 - 71. 
Richards SS, Sweet RA. (2008). "Dementia”. In Kaplan \& Sadock's comprehensive textbook of psychiatry. $9^{\text {th }}$ edition, Philadelpia/ tokyo; Lippincott William \& Wilkin; p 1167-1206

Busse A, Bischkopf J, Ridel-Heller SG, Angermeyer MC.(2003) "Mild Cognitiv Impairment Prevalence And Incidence According To Different Diagnostic Criteria". British Journal of Psychiatry, 182,449-454

Sadock BJ, Sadock VA. (2005) "Delirium Dementia, Amnestic Disorders, and Other Cognitive Disorders, and Mental Disorders Due to a General Medical Condition”. In Kaplan \& Sadock's pocket handbook of Clinical Psychiatri. 3rd edition. Philadelphia : Lippincott William \& Wilkins. P 33 - 45.

PERKENI. (2006). "Pengelolaan Diabetes Melitus Tipe-2”. In Konsensus Pengelolaan Dan Pencegahan Diabetes Melitus Tipe 2 Di Indonesia,

Sastroasmoro S, Ismael S. (2008). "Studi cross-sectional". In : Dasar-dasar Metodologi penelitian klinis. 3rd ed. Jakarta : Sagung Seto. P $113-25$.

\section{First A. Wijaya Taufik Tiji}

Birth in Medan $14^{\text {th }}$ September 1979. Educational background : graduate from elementary school (SD Jenderal Gatot Subroto Medan) in 1990, Graduate from junior high school( SLTP. St.Thomas 1 Medan) in 1993, graduate from senior high school (SLTA St. Thomas 1 Medan) in 1996, graduate from Medical College University of Sumatera Utara in 2002 with type of degree Medical Doctor, graduate from Magister Clinic of Medical (Magister Kedokteran) University of Sumatera Utara with type of degree M. Ked(KJ) in 2012, and currently study as a Resident of Psychiatry Department Medical Faculty of University of Sumatera Utara.

\section{Second A. Elmeida Effendy}

Medical Doctor (MD), Psychiatrist, graduate from Magister Clinic of Medical (Magister Kedokteran) University of Sumatera Utara with type of degree M. Ked(KJ) in 2012, graduate from doctoral in 2013.

\section{Third A. Mustafa M Amin}

Medical Doctor (MD), Psychiatrist, graduate from Magister Clinic of Medical (Magister Kedokteran) University of Sumatera Utara with type of degree M. $\operatorname{Ked}(\mathrm{KJ})$ in 2012, graduate from Master of Neuroscience from king's Collage University with type of degree Master of Science in 2013.

\section{Fourth A. Dharma Lindarto}

Medical Doctor (MD), Internist and graduate from doctoral in 2012. 
The IISTE is a pioneer in the Open-Access hosting service and academic event management. The aim of the firm is Accelerating Global Knowledge Sharing.

More information about the firm can be found on the homepage:

http://www.iiste.org

\section{CALL FOR JOURNAL PAPERS}

There are more than 30 peer-reviewed academic journals hosted under the hosting platform.

Prospective authors of journals can find the submission instruction on the following page: http://www.iiste.org/journals/ All the journals articles are available online to the readers all over the world without financial, legal, or technical barriers other than those inseparable from gaining access to the internet itself. Paper version of the journals is also available upon request of readers and authors.

\section{MORE RESOURCES}

Book publication information: http://www.iiste.org/book/

\section{IISTE Knowledge Sharing Partners}

EBSCO, Index Copernicus, Ulrich's Periodicals Directory, JournalTOCS, PKP Open Archives Harvester, Bielefeld Academic Search Engine, Elektronische Zeitschriftenbibliothek EZB, Open J-Gate, OCLC WorldCat, Universe Digtial Library, NewJour, Google Scholar

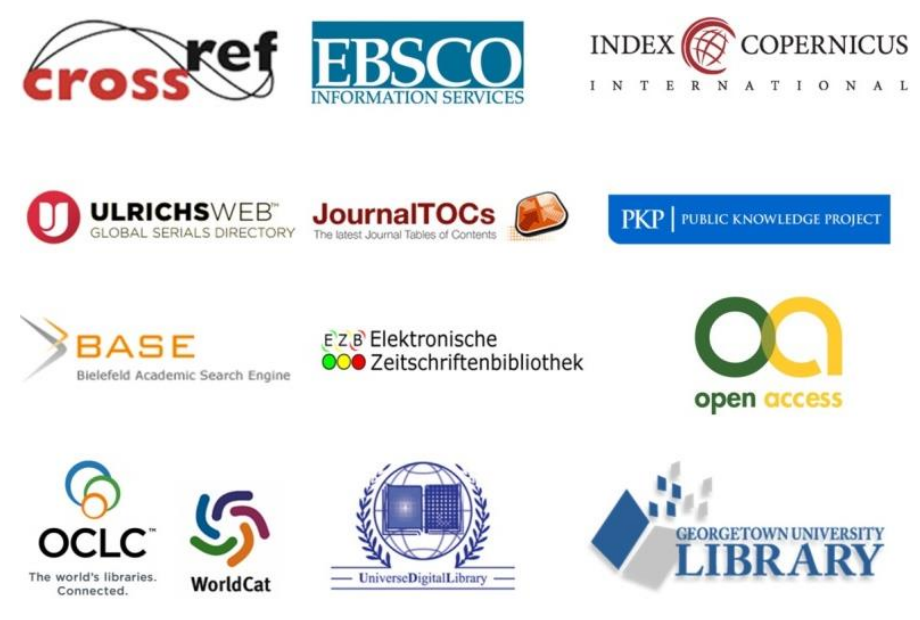

